\title{
HASIL BELAJAR SISWA DI MI NW PANCOR KOPONG PADA MASA PANDEMI COVID-19
}

\author{
Muh. Yazid ${ }^{1 *}$, Aluh Ernawati ${ }^{2}$ \\ ${ }^{1}$ Universitas Hamzanwadi Selong, NTB; ${ }^{2}$ MI NW Pancor Kopong, Lombok Timur, NTB \\ Jln. TGKH Zainuddin Abdul Madjid No.132, Pancor, Selong, Lombok Timur, NTB \\ *Corresponding Author: muhvazid@hamzanwadi.ac.id \\ Info Artikel

\section{Abstract} \\ Sejarah Artikel: \\ Diterima: 22/09/2020 \\ Direvisi: $24 / 09 / 2020$ \\ Disetujui:01/10/2020 \\ This study aims to determine student learning outcomes at MI NW Pancor Kopong during the \\ Covid-19 pandemic. The method used in this research is descriptive qualitative to determine \\ the extent of student learning outcomes. The population in this study were all students of MI \\ $N W$ Pancor Kopong, with the number of samples were Grade V. The results of this study were \\ Keywords: learning that the highest and lowest scores were obtained grouped according to the assessment criteria \\ outcome, covid-19 in schools, namely based on the value of the Minimum Completeness Criteria (KKM) to \\ pandemic determine student learning outcomes of class V MI NW Pancor Kopong. The minimum \\ completeness criteria (KKM) averaged 60. Data on learning outcomes obtained by grade VMI \\ NW Pancor Kopong even semester students of the 2019-2020 school year were successfully \\ obtained from UAS scores of 20 students. Quantitatively, the highest score was 80 achieved by \\ 3 students and the lowest total score was less than 60 which was achieved by 11 students and \\ besides that, the score was moderate.
}

\begin{abstract}
Abstrak
Penelitian ini bertujun untuk mengetahui hasil belajar siswa di MI NW Pancor Kopong pada mada pandemi covid-19. Metode yang digunakan dalam penelitian ini adalah qualitatiff deskriptif untuk mengetahui sejauhmana hasil belajar siswa. Adapun populasi dalam penelitian ini adalah semau siswa MI NW Pancor Kopong, dengan jumlah sampel adalah siswa kelas V. Adapun hasil penelitian ini adalah diperoleh nilai tertinggi dan terendah dikelompokkan sesuai dengan kriteria penilaian di sekolah, yaitu berdasarkan nilai Kriteria Ketuntasan Minimal (KKM) untuk mengetahui hasil belajar siswa kelas V MI NW Pancor Kopong. Adapun Kriteria Ketuntasan Minimal (KKM) rata rata 60. Data tentang hasil belajar yang diperoleh siswa kelas V MI NW Pancor Kopong semester genap tahun ajaran 2019-2020 yang berhasil diperoleh dari nilai UAS Sebanyak 20 orang siswa. Secara kuantitatif, skor tertinggi adalah 80 diraih oleh 3 siswa dan total skor terendah adalah kurang dari 60 yang diraih oleh 11 orang siswa dan selain itu medapatkan nilai sedang.
\end{abstract}

\footnotetext{
"Alamat korespondensi:

Universitas Hamzanwadi Selong

Jln. TGKH Zainuddin Abdul Madjid No.132, Pancor, Selong, Lombok Timur, NTB

E-mail : muhyazid@hamzanwadi.ac.id
}

(C) 2020 Program Studi PGSD Universitas Flores Email: primagistrauniflor@gmail.com 


\section{PENDAHULUAN}

Pendidikan formal memiliki visi dan misi yang sangat mulia yaitu mencerdaskan kehidupan berbangsan dan bernegara. Dalam Undang-Undang Nomor 20 Tahun 2003 tentang Sistem Pendidikan Nasional menyebutkan, bahwa pendidikan nasional berfungsi mengembangkan kemampuan dan membentuk watak serta peradaban bangsa yang bermartabat dalam rangka mencerdaskan kehidupan bangsa (Fitriyani, 2018). Oleh karna itu setiap warga negara memiliki hak dan kewajiban sebagai bagian dari negara. Salah satu hak yang harus diterima serta diberikan oleh negara adalah pendidikan formal secara merata tanpa melihat agama, budaya, suku, ras, etnis. Setiap warga negara berhak medapatkan pendidikan yang bermutu (Liang \& Zhang, 2016).

Pada awal abad 21 ini, tantangan yang dihadapi oleh negara sangatlah komplek dan beragam, baik itu tantangan teknologi, budaya, ekonomi, pendidian, kesehatan dan lain sebagainya (Tidjani, 2017). Tantangan yang paling berat yang berdampak pada sektor yang lain adalah pendidikan khususnya prestasi belajar siswa. Prestasi ada kaitannya dengan minat siswa dalam belajar, tercatat Indonesia menempati urutan ke 108 dunia dan posisi kedua dari bawah seasia tenggara. Indonesia kalah jauh dari negara - negara tetangga.

Undang-undang Pendidikan No. 20 Tahun 2003 Tentang Sistem Pendidikan Nasional yang berfungsi mengembangkan kemampuan membentuk watak dan peradaban bangsa yang bermartabat dalam rangka mencerdaskan kehidupan bangsa bertujuan untuk mengembangkan potensi peserta didik agar menjadi manusia yang beriman dan bertaqwa kepada Tuhan Yang Maha Esa berakhlak mulia, sehat, berilmu, cakap, kreatif, mandiri dan menjadi warga negara yang demokratis dan peka terhadap tantangan zaman (No, 20 C.E.). Jika kita melihat dari fungsi pendidikan secara nasional berdasarkan Undang-Undang diatas, jelas bahwa pendidikan dilaksanakan dengan perencanaan yang betul betul matang dan terarah.

Untuk mewujudkan sistem pendidikan maka perlu ada langkah secara nyata dan terencana dari semua unsur dan pihak yang tidak bisa dipisah antara satu dengan yang lainnya adalah kegiatan proses belajar mengajar di kelas ataupun di sekolah. Arartinya bahwa berhasil tidaknya pencapaian tujuan pendidikan secara nasional banyak bergantung kepada bagaimana pencapaian pendidikan yang dialami siswa yang mencakup aspek kongnitif, afektif dan psikomotorik. Dalam suatu lembaga pendidikan keberhasilan proses belajar mengajar dapat di lihat juga dari prestasi belajar yang dicapai oleh peserta didik. Prestasi belajar mempunyai hubungan erat dengan kegiatan belajar, banyak faktor yang mempengaruhi prestasi belajar baik yang berasal dari dalam individu itu sendiri mauupun faktor yang berasal dari luar individu. Menurut (Riyani, 2015), faktorfaktor yang mempengaruhi prestasi belajar adalah : a) Faktor dari dalam diri individu Terdiri dari faktor fisiologis. Faktor fisiologis adalah kondisi jasmani dan kondisi panca indera. Sedangkan faktor psikologis yaitu bakat, minat, kecerdasan, motivasi berprestasi dan kemampuan kognitif. b) Faktor dari luar individu Terdiri dari faktor lingkungan dan faktor instrumental. Faktor lingkungan yaitu lingkungan sosial dan lingkungan alam.Sedangkan faktor instrumental yaitu kurikulum, bahan, guru, sarana, administrasi, dan manajemen.

Prestasi belajar terwujud karena adanya perubahan selama beberapa waktu yang tidak disebabkan oleh pertumbuhan, tetapi karena adanya situasi belajar, prestasi belajar seseorang umumnya ditunjukkan dalam bentuk nilai rata - rata yang diperoleh. Sedangkan menurut (Hiebert et al., 2007) prestasi belajar adalah tingkat keberhasilan siswa dalam mencapai tujuan yang ditetapkan dalam sebuah program pembelajaran.

Upaya yang dilakukan oleh pemerintah yang dalam hal ini sekolah sebagai ujung tombak pendidikan sangat maksimal, akan tetapi kenyataan yang sangat berbeda dari harapan yang ada. Disamping sekolah ingin meningkatkan prestasi belajar siswa disaat yang bersamaan juga terjadi bencana non alam berupa covid 19. Covid 19 merupakan masalah baru bagi dunia pendidikan. Pemerintah 
Indonesia telah menghimbau semua warga untuk tetap berada di rumah. Salah satunya Pemerintah Indonesia menerapkan aturan PSBB yang merupakan singkatan dari Pembatasan Sosial Berskala Besar yang dibuat dalam rangka Penanganan atau pencegahan Covid-19. Hal ini dilakukan oleh pemerintah dengan harapan virus tidak menyebar lebih luas dan upaya penyembuhan dapat berjalan maksimal dan sesuai dengan harapan bersama. Dalam usaha pembatasan sosial ini pemerintah Indonesia juga telah membatasi kegiatan diluar rumah seperti kegiatan pendidikan yang telah dilakukan melalui pembelajaran online ataupun dengan cara yang lain seperti pemberian tugas dan lain lain.

Pembelajaran online dilakukan dengan memanfaatkan teknologi khususnya internet dan hanphone ataupun laptop (Setiawati et al., 2012). Pembelajaran online dilakukan dengan sistem belajar jarak jauh, dimana Kegiatan Belajar dan Mengajar (KBM) tidak dilakukan secara tatap muka. Pembelajaran dilakukan dengan menggunakan media, baik media cetak (modul) maupun non cetak (audio/video), komputer/internet, siaran radio dan televisi dan yang lainnya (Ahmadi, 2017; Wiradharma et al., 2020). Pada pembelajaran online, peserta didik dapat menjadi kurang aktif dalam menyampaikan pendapat dan pemikirannya, sehingga dapat mengakibatkan pembelajaran yang dilakukan dengan during mengibatkan siswa jenuh dalam belajar serta tidak jarang diantara meneka memoprasikan aplikasi yang lain seperti main game dan yang lainnya. Seorang siswa yang mengalami kejenuhan dalam belajar akan memperoleh ketidakmajuan dalam prestasi belajar (Pramuditya et al., 2017; Syahran, 2015). Oleh karena itu, diperlukan pendorong untuk menggerakkan siswa agar semangat belajar tidak kendor sehingga dapat memiliki prestasi belajar yang maksimal dan sesuai dengan espektasi orang tua.

Minat belajar memang sangat berpengaruh pada diri seseorang dalam meningkatkan prestasinya. Dengan adanya minat seseorang akan melakukan sesuatu hal yang menghasilkan sesuatu agar dapat meningkatkan prestasinya dalam bidang pendidikan. Guru harus berusaha membangkitkan minat belajar siswa supaya siswa menguasai pengetahuan yang terkandung dalam mata pelajarannya. Salah satu cara guru untuk menimbulkan minta siswa adalah dengan menumbuhkan perasaan senang akan menimbulkan minat belajar yang pada ahirnya akan meningkatkan prestasi belajar siswa (DeBoer, 2019; Slavin, 2019). sebaliknya perasaan yang tidak senang menghambat dalam belajar karena tidak melahirkan sikap yang positif dan tidak menunjang minat dalam belajar.

Berdasarkan latar belakang tersebut tujuan dari penelitian ini adalah untuk mengetahui seberapa besar prestasi belajar siswa pada masa pandemi covid 19 di MI NW Pancor Kopong.

\section{METODE PENELITIAN}

Penelitian ini termasuk penelitian deskriptif korelasional yang bertujuan untuk mendeskripsikan dan mengetahui hasil belajar siswa di masa pandemi covid 19. Penelitian ini terdiri dari dua variabel, yaitu; pandemi covid 19 merupakan variabel bebas dan hasil belajar merupakan variabel terikat. Populasi penelitian ini adalah semua siswa kelas kelas I sampai kelas VI MI NW Pancor Kopong yang berjumlah 115 dan adapun jumlah sampel dalam penelitian ini adalah kelas $\mathrm{V}$ berjumlah sebanyak 20 orang. Alat pengumpul data berbentuk angket. Prosedur yang ditempuh dalam pengumpulan data adalah dengan membagikan angket kepada sampel penelitian. Data yang telah terkumpul akan dianalisis dengan menggunakan teknik persentase (\%).

\section{HASIL DAN PEMBAHASAN}

\section{Hasil penelitian}

Perolehan hasil belajar siswa dalam penelitian ini diukur dengan indikator yaitu nilai Ujian Akhir Semester kelas V MI NW Pancor Kopong. Dari nilai tersebut diperoleh nilai tertinggi dan terendah dikelompokkan sesuai dengan kriteria penilaian di sekolah, yaitu berdasarkan nilai Kriteria Ketuntasan Minimal (KKM) untuk mengetahui hasil belajar siswa kelas V MI NW Pancor Kopong. Adapun Kriteria Ketuntasan Minimal (KKM) rata rata $60-65$. Data tentang hasil belajar yang diperoleh siswa kelas V MI NW Pancor 
Kopong semester genap tahun ajaran 20192020 yang berhasil diperoleh dari nilai UAS Sebanyak 20 orang siswa. Secara kuantitatif, skor tertinggi adalah 80 diraih oleh 3 siswa dan total skor terendah adalah kurang dari 60 yang diraih oleh 11 orang siswa dan selain itu medapatkan nilai sedang.

\section{Tabel 1}

Nilai hasil UAS kelas V MI NW Pancor Kopong

\begin{tabular}{llll}
\hline $\begin{array}{l}\text { Rentang } \\
\text { nilai }\end{array}$ & Kriteria & Jumlah & Persentase \% \\
\hline $40-59$ & Rendah & 11 & $55 \%$ \\
\hline $60-79$ & Sedang & 6 & $30 \%$ \\
\hline $80-100$ & Tinggi & 3 & $15 \%$ \\
\hline Jumlah & & 20 & $100 \%$ \\
\hline
\end{tabular}

Berdasarkan hasil pengolahan data secara statistik deskriptif di atas dapat diketahui bahwa siswa, sebagian besar belum mencapai ketuntasan belajar sebesar $55 \%$. Oleh karena itu dapat disimpulkan berdasarkan persentase tertinggi sebesar $15 \%$ berada pada rentang 60-100 menunjukkan bahwa hasil belajar siswa Kelas V MI NW Pancor Kopong tergolong atau berada dalam kategori sedang dan rendah.

\section{Pembahasan}

Hasil penelitian mengungkapkan bahwa hasil belajar siswa yang dimiliki olehsiswa dapat dikategorikan pada tingkat sedasang artinya tidak terlalu baik dan tidak juga terlalu buruk dengan persentase kategori adalah $45 \%$ sedang sampai tuntas, namun banyak juga siswa yang memiliki hasil belajar dalam kategori rendah dengan persentasi 55\%. Dilihat dari hasil belajar yang diperoleh siswa MI NW Pancor Kopong, meliputi kesiapan siswa dalam belajar, menunjukan bahwa hasil belajar siswa berada pada kategori cukup.

Hasil belajar yang dimaksud dalam penelitian ini tidak hanya dilihat dari hasil tes peserta didik akan tetapi dilihat dari kesiapan belajar siswa pada masa pandemi covid-19 yang meliputi: motivasi belajar siswa, proses belajar, suasana belajar, kesiapan belajar, dukungan orang tua, dan media belajar.

Pada masa pandemi covid 19, guru punya kewajiban untuk membangkitkan motivasi belajar siswa. Memotivasi siswa dalam belajar penting dilakukan oleh guru selama masa pandemi ini. Memotivasi siswa dimasa pandemi dilakukan dengan mendatangi siswa ke rumahnya. Ini dilakukan untuk memastikan siswa belajar dirumah guna untuk mempertahankan dan meningkatkan hasil belajarnya. Selain membangkitkan motivasi belajar siswa dalam belajar, guru juga punya kewajiban dalam proses belajar siswa, proses belajar pada masa pandemi ini dilakukan sedemikian baik oleh guru mualai dari perencanaan, pelaksanaan sampai evaluasi diakhir pembelajaran guna memastikan hasil belajar siswa bisa dipertahankan dan ditingkatkan.

Selain membangkitkan motivasi belajar siswa, serta memastikan proses berjalan dengan baik dan maksimal, guru juga dituntut untuk mensesain suasana belajar agar kondusif dan menyenangkan bagi peserta didik. MI NW Pancor Kopong, sebagian guru pergi kerumah siswa untuk malakukan proses pembelajaran di rumah. Siswa yg berdekatan rumahnya diminta untuk belajar bersama disalah satu rumah siswa lalu guru datang untuk melaksanakan pembelajaran. Disamping itu, guru juga menyiapkan media yang dibutuhkan dalam proses belajar.

\section{SIMPULAN DAN SARAN}

\section{Simpulan}

Berdasarkan hasil penelitian yang di peroleh, maka dapat disimpulkan sebagai berikut: a). Hasil belajar di MI NW Pancor Kopong berada pada kategori rendah, dimana sebagian besar siswa belum memiliki hasil yang maksimal. b). Masih banyak siswa dan guru belum siap dalam mengahdapi belajr dengan pola daring, dikarenakan siswa banyak yang belum meiliki sarana yang mendukung. c). Terdapat pengaruh yang signifikan covid 19 terhadap prestasi belajar siswa di MI NW Pancor Kopong.

\section{Saran}

Bagi guru : sebagai bahan pertimbangan dalam mengembangkan metode atau media yang lebih tepat dan sesuai dengan kebutuhan siswa pada masa pandemi ini. hal ini bisa dilakukan seperti memberikan layanan informasi, bimbingan kepada siswa 
baik secara mandiri maupun secara kelompok dalam belajar luring maupun daring. agar dapat dapat belajar dengan optimal dirumah maupun di tempat lain yang mendukung.

Bagi orang tua: diharapkan dapat memantau perkembangan belajar dan proses belajar siswa dirumah, agar siswa daqpat mempertahankan dan meningkatkan hasil belajarnya.

Bagi siswa: agar dapat memapaatkan situasi dan kondisi pandemi ini dengan baik dan bijak dalam belajar, agar prestasi belajarnya dapat dipertahankan dan ditingkatkan

\section{DAFTAR PUSTAKA}

Ahmadi, F. (2017). Guru SD di Era Digital: Pendekatan, Media, Inovasi. CV. Pilar Nusantara.

DeBoer, G. (2019). A history of ideas in science education. Teachers College Press.

Fitriyani, P. (2018). Pendidikan karakter bagi generasi Z. Prosiding Konferensi Nasional Ke-7 Asosiasi Program Pascasarjana Perguruan Tinggi Muhammadiyah Aisyiyah (APPPTMA). Jakarta, 23-25.

Hiebert, J., Morris, A. K., Berk, D., \& Jansen, A. (2007). Preparing teachers to learn from teaching. Journal of Teacher Education, 58(1), 47-61.

Liang, M., \& Zhang, Q. (2016). A Brief Talk on how to Actively Adapt to Urbanization Development and Promote New Citizens' Quality Education: A Case Study of Bao'an District, Shenzhen. International Conference on Humanities and Social Science 2016.

No, U.-U. (20 C.E.). tahun 2003 tentang sistem Pendidikan Nasional.

Pramuditya, S. A., Noto, M. S., \& Syaefullah, D. (2017). Game Edukasi Rpg Matematika. Eduma: Mathematics Education Learning and Teaching, 6(1), 77-84.

Riyani, Y. (2015). Faktor-faktor yang mempengaruhi prestasi belajar mahasiswa (studi pada mahasiswa Jurusan Akuntansi Politeknik Negeri Pontianak).

Setiawati, N., Kartika, I., \& Purwanto, J. (2012). Pengembangan mobile learning (m-learning) berbasis Moodle sebagai daya dukung pembelajaran fisika di SMA. Seminar Nasional Fisika Dan Pendidikan Fisika Ke-2 2012.

Slavin, R. E. (2019). Educational psychology: Theory and practice.

Syahran, R. (2015). Ketergantungan online game dan penanganannya. Jurnal Psikologi Pendidikan Dan Konseling: Jurnal Kajian Psikologi Pendidikan Dan Bimbingan Konseling, 1(1), 84-92.

Tidjani, A. (2017). Manajemen Lembaga Pendidikan Islam Menghadapi Tantangan Globalisasi. Reflektika, 12(1), 96-133.

Wiradharma, G., Arisanty, M., Saputra, A. H., Anam, K., \& Robiansyah, A. (2020). The Video Online Learning Guides for Beginner College Students. Dinamisia: Jurnal Pengabdian Kepada Masyarakat, 4(3), 391-397. 